\title{
Biochemically based modeling study of Antarctic krill Euphausia superba growth and development
}

\author{
Bettina A. Fach ${ }^{1,2, *}$, Bettina Meyer ${ }^{1}$, Dieter Wolf-Gladrow ${ }^{1}$, Ulrich Bathmann ${ }^{1}$ \\ ${ }^{1}$ Alfred Wegener Institute for Polar and Marine Research, Am Handelshafen 12, 27570 Bremerhaven, Germany \\ ${ }^{2}$ Institute of Marine Sciences, Middle East Technical University, PO Box 28, 33731 Erdemli, Turkey
}

\begin{abstract}
A biochemical model of Antarctic krill Euphausia superba was developed to investigate the physiological mechanisms which enable krill to survive winter, when food is scarce. In this modeling approach data sets on the biochemical composition of krill and its food sources are combined into a model that takes food quality into account rather than just food availability during different seasons. Krill is defined in terms of protein, neutral lipid, polar lipid, carbohydrate, chitin, and ash content, and the model tracks krill neutral lipid content separately from weight. The model includes parameterizations of filtration, ingestion, and metabolic processes which determine krill growth rate. Initial ratios of protein, neutral lipid, polar lipid, carbohydrate and ash change in chitin response to the biochemical composition of food as krill grows. Model results show that a diet of phytoplankton food alone may be sufficient for krill to grow to observed sizes but may not be sufficient to provide the summer lipid resources that are observed in the field and that are necessary for krill to reproduce and survive winter. The inclusion of sea ice algae as an additional food is beneficial for krill at the end of winter but does not significantly change summer krill lipid content. However, the amount of lipids accumulated within krill increases significantly when krill feeds on lipid-rich heterotrophic food, which points to the importance of carnivory, even in times when phytoplankton food is available. The strategy of combusting body components to produce energy (shrinking) is found to provide the greatest source of energy for krill of all sizes during times of prolonged starvation.
\end{abstract}

KEY WORDS: Antarctic krill · Biochemical $\cdot$ Growth model $\cdot$ Food quality $\cdot$ Overwinter strategies

\section{INTRODUCTION}

During austral winter much of the Southern Ocean is covered by sea ice and phytoplankton, the main food source of Antarctic krill Euphausia superba, is scarce. The overwintering strategy Antarctic krill employs to survive this time is of central importance for estimating krill population dynamics and has been the topic of debate for some time. E. superba mainly accumulates triacylglycerols as storage lipid during times of high food supply and increased body lipid levels, as well as smaller amounts of phospholipid (Hagen et al. 1996). Compared to other euphausiids, Antarctic krill does not produce high lipid reserves and lacks wax esters, which suggests omnivorous and year-round feeding
(Clarke 1980, Sargent et al. 1981, Atkinson \& Snÿder 1997). It has been suggested that for different life stages of krill lipid reserves are of different importance and are influenced by seasonal factors (Hagen et al. 2001, Atkinson et al. 2002, Meyer et al. 2002).

Studies suggest that krill may make use of a variety of overwintering mechanisms, including extensive lipid utilization (Hagen et al. 2001, Atkinson et al. 2002), severely lowered metabolic rates (Torres et al. 1994), and the use of their body structure causing a shrinkage in size (Ikeda \& Dixon 1982, Torres et al. 1994). Other recent studies showed that adult krill had a $30 \%$ reduced ingestion rate in fall compared to summer with a 60 to $80 \%$ reduced metabolic rate (Atkinson et al. 2002); at the same time carnivory increased. 
The energy budget calculated by Atkinson et al. (2002) showed that adult krill can survive more than 200 d, and thereby the complete winter, on their own lipid and protein stores. However, krill larvae have been shown not to reduce their metabolism during fall and therefore need to exploit other food sources during winter (Meyer et al. 2002).

The importance of these different strategies for adult krill survival and how they relate to population development and recruitment success is not known. Mathematical models provide one approach for exploring the effect of different strategies on the growth and survival of different life stages of Antarctic krill. Hofmann \& Lascara (2000) developed a time-dependent, sizestructured krill growth model to examine the growth dynamics of krill. They found that the model produces spring and summer growth rates for different size classes that are consistent with observations when krill is feeding on phytoplankton; however, the simulated annual growth cycle for larval and subadult krill best matches observations when winter respiration rates are reduced and sea ice algae is available as an additional food source.

In other modeling studies Fach et al. $(2002,2006)$ assessed the amount of food needed to sustain Antarctic krill during transport across the Scotia Sea to South Georgia, using drifter paths from a circulation model (Fach \& Klinck 2006). Their simulation results show that phytoplankton concentrations across the Scotia Sea are not sufficient to support krill survival during transport from the Antarctic Peninsula to South Georgia and that including sea ice algae food does not alter this result. They point to the importance of other food sources such as heterotrophic food and detritus.

Recently, Kawaguchi et al. (2006) and Candy \& Kawaguchi (2006) developed a linear mixed model to simulate the instantaneous growth rate of krill as a function of a temperature-dependent inter-moult period. At the same time Atkinson et al. (2006) developed an instantaneous growth rate model that predicts krill growth depending on food, temperature, body length, sex, and maturity stage of krill. This provides a method of predicting krill growth from environmental variables such as chlorophyll a (chl a) and temperature, which are available via remote sensing, on a basin-wide scale. However, by using satellite images of phytoplankton concentration as a basis for this calculation, such models do not take into account the fact that krill is known to feed on sea ice algae, copepods, and detritus as well as phytoplankton. In addition, such models cannot give any information about possible krill overwintering strategies.

The objective of the current study is to investigate how different krill life stages survive the winter months when food is scarce. Specifically, the impor- tance of overwintering mechanisms for different krill stages, as well as the influence of different food types available to krill with respect to the quality of food and energetic supply to krill, is of interest. A biochemical, individual-based model of krill metabolism was used that allows krill to grow or shrink continuously depending on food supply and food quality. The novel approach of this type of krill model is that it considers not only food quantity but also food quality, such as previous models have done for oysters (Bochenek et al. 2001). It defines krill in terms of their protein, neutral lipid, polar lipid, carbohydrate, chitin, and ash content and therefore is able to consider simple biochemical processes within krill.

\section{MODEL DESCRIPTION}

Model structure. The governing equation of the model is the rate of change in krill length over time given by:

$$
\frac{\mathrm{d} L}{\mathrm{~d} t}=\mu \cdot L
$$

where $L$ is krill length $(\mathrm{mm})$ and $\mu\left(\mathrm{d}^{-1}\right)$ is the growth rate. The growth of krill is based on formulations that allow differential metabolism of protein, lipid, and carbohydrate content of the food ingested by krill. It depends on net production (NP, $\mathrm{J} \mathrm{d}^{-1}$ ) of the 6 basic biochemical components (index i) included in the model: protein, polar lipid, neutral lipid, carbohydrate, chitin, and ash. Net production is defined as:

$$
\mathrm{NP}_{i}=\mathrm{AI}_{i}-R_{i}
$$

where $\mathrm{AI}_{i}$ is assimilated food $\left(\mathrm{J} \mathrm{d}^{-1}\right)$, and $R_{i}$ is the total respiration of krill $\left(\mathrm{J} \mathrm{d}^{-1}\right)$, both dependent on the size of krill. The 6 basic biochemical components are tracked in the model and an increase in krill length occurs when the sum of the 6, i.e. $\sum_{i=1}^{6} \mathrm{NP}_{i}$, is positive and when restrictions on selected biochemical ratios are simultaneously met. The metabolized food is then converted into the structural components of krill. When respiration exceeds assimilated food, krill gains energy from utilizing storage material as well as structural components and may shrink in size.

Changes in krill length are coupled to changes of krill dry weight (DW), wet weight (WW) and carbon weight $(\mathrm{CW})$ and are tracked in the model. Assimilated food is calculated as:

$$
\mathrm{AI}_{i}=\mathrm{AE}_{i} \cdot \gamma \cdot F^{\mathrm{cf}} \cdot \operatorname{food}_{i}(t)
$$

where $\mathrm{AE}_{i}$ is the assimilation efficiency (\%), $\gamma$ is the fraction krill spends feeding (dimensionless), and $F^{\mathrm{cf}}$ is the compression filtration rate $\left(\mathrm{m}^{3} \mathrm{~d}^{-1}\right)$ that changes depending on krill size (see Hofmann \& Lascara 2000, Fach et al. 2002). The feeding fraction $\gamma$ is specified to be a constant 
Table 1. Parameters used in the model. Their definition, units, reference value, and range are listed together with results of changes in dry weight (\%DW) of the sensitivity analysis

\begin{tabular}{|c|c|c|c|c|}
\hline Parameter & Definition & Units & Value (range) & \% change in DW \\
\hline$\mu_{\max }$ & Maximum growth rate & $\mathrm{mm} \mathrm{d}^{-1}$ & $0.07(0.04-0.1)$ & $-22,+13$ \\
\hline$\gamma$ & Time spent feeding & $\%$ & $75(65-85)$ & $-11,+9.4$ \\
\hline$r_{\mathrm{pl}: \mathrm{nl}}$ & Min. polar lipid:neutral lipid ratio in respiration & None & $0.2(0.1-0.3)$ & $+7.5,-2.1$ \\
\hline $\mathrm{AE}_{\mathrm{pr}}$ & Assimilation efficiency of protein & $\%$ & $100(80-100)$ & $-7.4,+0.0$ \\
\hline $\mathrm{AE}_{\mathrm{nl}}$ & Assimilation efficiency of neutral lipid & $\%$ & $100(80-100)$ & $-1.5,+0.0$ \\
\hline $\mathrm{AE}_{\mathrm{pl}}$ & Assimilation efficiency of polar lipid & $\%$ & $100(80-100)$ & $-7.1,+0.0$ \\
\hline $\mathrm{AE}_{\text {carb }}$ & Assimilation efficiency of carbohydrate & $\%$ & $20(10-30)$ & $-2.4,+2.2$ \\
\hline PL:Pr & Polar lipid:protein ratio & None & $f(\mathrm{DW})(+10 \%,-10 \%)$ & $-2.1,+2.0$ \\
\hline Carb:Pr & Carbohydrate:protein ratio & None & $f(\mathrm{DW})(+10 \%,-10 \%)$ & $-0.7+0.9$ \\
\hline Chi:Pr & Chitin:protein ratio & None & $f(\mathrm{DW})(+10 \%,-10 \%)$ & $+0.2,-0.05$ \\
\hline Chi:Carb & Chitin:carbohydrate ratio & None & $f(\mathrm{DW})(+10 \%,-10 \%)$ & $-0.5,+0.8$ \\
\hline Pr:Ash & Protein:ash ratio & None & $f(\mathrm{DW})(+10 \%,-10 \%)$ & $-3.5+3.7$ \\
\hline \multirow[t]{2}{*}{ C:chl } & Carbon:chlorophyll ratio & $\mathrm{mg} \mathrm{m}^{-3} \mathrm{C}$ & $50(40-60)$ & $-51,+29$ \\
\hline & & $\overline{\mathrm{mg} \mathrm{m}^{-3} \operatorname{chl} a}$ & & \\
\hline
\end{tabular}

with a value of 0.9 for larval krill $(<12 \mathrm{~mm})$ and 0.75 for larger krill ( $\geq 12 \mathrm{~mm})$. It has been defined to include the observation that krill is an animal that alternates between area-intensive feeding and long-distance foraging movements (Hamner 1984). Krill in the model mainly uses compression filtration when feeding. However, when krill is assumed to feed on ice algae underneath sea ice during which time krill uses the thoracic appendages (Hamner et al. 1983), the filtration rate is assumed to be $5 \%$ of $F^{\mathrm{cf}}$ (Hofmann \& Lascara 2000).

$\mathrm{AE}_{i}$ is defined to be $100 \%$ for protein and lipid content, but is $20 \%$ for carbohydrate according to Handa (1969), who gives these efficiency values for plant material. The $\mathrm{AE}_{i}$ for carbohydrate is so low because $80 \%$ of the plant carbohydrate is structural and cannot be digested by animals, and is therefore not available as food. The remaining $20 \%$ represent labile carbohydrate. These combined efficiencies result in an overall assimilation efficiency for krill of $80 \%$, which falls within the range ( 72 to $94 \%$ ) observed for krill by Kato et al. (1982). Unassimilated food is assumed to be lost as fecal pellets. For a list of the main parameters used in the biochemical model please see Table 1.

Krill respiration $R\left(\mathrm{~J} \mathrm{~d}^{-1}\right)$ is defined as:

$$
R=R^{\mathrm{s}}(1+\zeta+\varepsilon)
$$

where $R^{\mathrm{s}}\left(\mathrm{J} \mathrm{d}^{-1}\right)$ is the standard metabolic rate that is dependent on krill size, $\varepsilon$ (dimensionless) is the feeding activity, and $\zeta$ (dimensionless) the reduced activity in winter (see Hofmann \& Lascara 2000, Fach et al. 2002). The calculation of $R^{\mathrm{s}}$ (see Hofmann \& Lascara 2000, their Table 3) thereby indirectly includes the energy cost of moulting.

Maximum growth rates $\left(\mu_{\max }\right)$ are defined sizedependent for krill in the model, because the range of observed growth rates is large and depends on krill size, e.g. 0.105 to $0.179 \mathrm{~mm} \mathrm{~d}^{-1}$ (Rosenberg et al. 1986) and $0.33 \mathrm{~mm} \mathrm{~d}^{-1}$ (Clarke \& Morris 1983). However, Siegel \& Nicol (2000) summarized available data sets for growth rates and found that larvae grow at 0.13 to $0.16 \mathrm{~mm} \mathrm{~d}^{-1}$, while juveniles older than $1 \mathrm{yr}$ (Age 1+) grow at 0.12 to $0.148 \mathrm{~mm} \mathrm{~d}^{-1}$, and older krill grow only at 0.025 to $0.07 \mathrm{~mm} \mathrm{~d}^{-1}$. Therefore, 3 separate $\mu_{\max }$ were defined for adult $\left(0.07 \mathrm{~mm} \mathrm{~d} \mathrm{~d}^{-1}\right)$, juvenile $\left(0.148 \mathrm{~mm} \mathrm{~d}^{-1}\right)$, and larval krill $\left(0.16 \mathrm{~mm} \mathrm{~d}^{-1}\right)$.

Biochemical conversions. A basic assumption for zooplankton is that polar lipid represent somatic tissue, neutral lipids represent any form of lipid reserves and that the formation of structural components determines animal growth. Therefore, material converted into the storage component neutral lipid does not result in an increase in krill length in the model. This approach has been used for simplicity although it has been hypothesised that Euphausia superba may accumulate phosphoglycerides as storage lipids (Saether et al. 1985, Hagen 1988, Hagen et al. 1996), which indicates that it is difficult to strictly separate polar and neutral lipids of krill into structural and storage components.

Observations from field and laboratory studies were used to derive the relationships that describe the processes affecting krill net production. A regression of protein content (\%DW) of krill versus krill DW, as well as carbohydrate content ( $\%$ DW) to krill DW was calculated from a compilation of data such as Ferguson \& Raymont (1974), Torres et al. (1994, pers. comm.), Meyer et al. (2002, 2003, unpubl. data), and Atkinson et al. (2002) (Fig. 1A,B):

$$
\begin{gathered}
\text { Protein } 039.3-0.02 \text { DW } \\
\mathrm{n}=233, \mathrm{r}=0.971, \mathrm{p}<0.05
\end{gathered}
$$



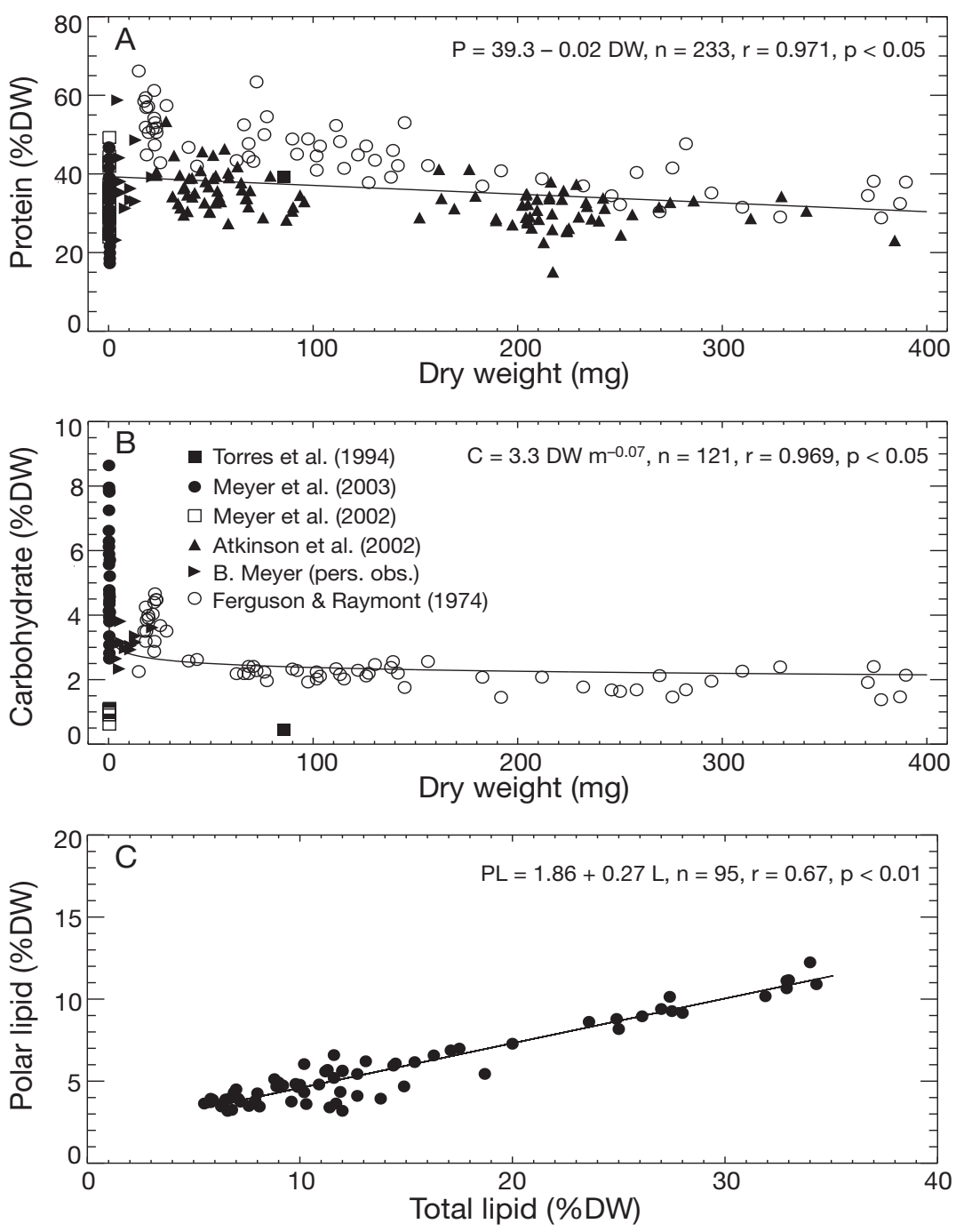

Fig. 1. Euphausia superba. Relationships between biochemical components calculated from krill observations: (A) protein to dry weight (DW) and (B) carbohydrate to DW. Data sources as indicated in (B). (C) Relationship of polar lipid to total lipid calculated after data from Hagen (1988). P: protein; C: carbohydrate; PL: polar lipid; L: total lipid

$$
\begin{aligned}
& \text { Carbohydrate }=3.3 \mathrm{DW}^{-0.07} \\
& \mathrm{n}=121, \mathrm{r}=0.969, \mathrm{p}<0.05
\end{aligned}
$$

To define a chitin content (\%DW) to DW relationship only few mean chitin values for pooled krill (Roschke \& Schreiber 1977), adult krill (Clarke 1980), and aquarium-reared juvenile and adult krill (Nicol et al. 1992) are available. Calculating the linear regression from their mean values yields:

$$
\begin{aligned}
& \text { Chitin }=2.88+0.01 \text { DW } \\
& \mathrm{n}=4, \mathrm{r}=0.995, \mathrm{p}<0.01
\end{aligned}
$$

while the ash weight (mg) to DW relationship in krill is taken from Clarke (1976):

$$
\begin{gathered}
\text { Ash }=0.94+0.12 \text { DW } \\
\mathrm{n}=311, \mathrm{r}=0.989, \mathrm{p}<0.01
\end{gathered}
$$

For krill <15 $\mathrm{mm}$ both chitin and ash relationships were calculated by spline interpolation. An important relationship for this model set up is the polar lipid (\%DW) to total lipid (\%DW) relationship (Fig. 1C) that has been calculated using data available from Hagen (1988):

$$
\begin{gathered}
\text { Polar lipid }=1.86+0.272 \text { lipid } \\
\mathrm{n}=67, \mathrm{r}=0.956, \mathrm{p}<0.01
\end{gathered}
$$

valid for lipid values greater than $5 \%$ of krill DW.

The fate of assimilated food, parameterized in terms of the biochemical constituents, differs within krill. Assimilated protein has as its primary destination the somatic tissue protein pool. Assimilated carbohydrate goes primarily to the carbohydrate pool, where it is used to maintain a certain protein-to-carbohydrate ratio within krill calculated from observations (Fig. 1) and is used for the production of chitin. Excess carbohydrate is stored in the neutral lipid pool. Assimilated polar lipid has as its primary destination the somatic tissue polar lipid pool and excess goes to the neutral lipid pool, where assimilated neutral lipid is also stored.

Conversions between different biochemical constituents in the tissue were done based on the different carbon molecular weights of lipids (palmitic acid), carbohydrates (glucose), protein (serine) and chitin while conserving carbon atoms (Bochenek et al. 2001). The ratio of the molecular weight of each constituent to its number of carbon atoms was calculated, and the resultant relative weights of the constituents were compared to each other (Bochenek et al. 2001). This yields a ratio of tissue carbohydrate to tissue lipid of $0.539\left(\mathrm{mg} \mathrm{mg}^{-1}\right)$, tissue protein to tissue lipid of $0.46\left(\mathrm{mg} \mathrm{mg}^{-1}\right)$, and tissue carbohydrate to chitin of $0.85\left(\mathrm{mg} \mathrm{mg}^{-1}\right)$.

Respiration needs are the only metabolic losses of assimilated energy in the krill model. The assimilated carbohydrate pool is the first reservoir used to meet energy demands. The needed carbohydrates are removed, while keeping the protein-to-carbohydrate ratio. If the assimilated carbohydrate pool is not suffi- 
cient, the remaining deficit is taken from the other assimilated pools. Any remaining deficit is then taken from the neutral lipid pool until a minimum neutral lipid to polar lipid ratio defined according to data from Hagen (1988) is reached. Any further energetic needs are then met by using structural components of krill. Periods in which krill resorts to using structural material to cover metabolic costs result in a reduction of the overall condition of krill that shows as a reduction in the protein-to-ash ratio and may result in shrinking. At any point in the development of krill, the inability to maintain one of the biochemical constituent ratios, or the inability to remove a deficit in one of the pools, results in death of krill.

Krill shrink when they do not encounter enough food to meet their metabolic needs and are starving (Ikeda \& Dixon 1982, Nicol et al. 1992). Ikeda \& Dixon (1982) show that the decrease in body wet weight of krill starved over $211 \mathrm{~d}$ ranged from 32 to $52 \%$ with a mean over $45 \%$. A loss of krill body wet weight of $45 \%$ is therefore assumed to be equivalent to the death of the individual in the model and the simulations are ended at this point. Larval krill have less tolerance to starvation and reach their point of no return faster, within $6 \mathrm{~d}$ (Ikeda 1984a,b, Meyer \& Oettel 2005). Therefore, larval krill in the model are assumed to die after $6 \mathrm{~d}$ without feeding.

The main parameters used in the biochemical model are listed in Table 1. Other parameters used for conversions between krill length and weight and dry weight are based on large data sets and have already been published elsewhere (Hofmann \& Lascara 2000, Fach et al. 2002). The same is true for the parameterization used to define the respiration and filtration rates of krill.

Food sources. Krill is known to feed predominantly on phytoplankton (Holm-Hansen \& Huntley 1984, Quetin \& Ross 1985, Schnack 1985). Therefore krill in the model is assumed to do the same. As the model allows for differential metabolism of protein, polar lipid, neutral lipid, and carbohydrate, the food ingested by krill needs to be expressed in terms of the relative contribution of each biochemical component. Based on studies on marine algae by Lee et al. (1971) and Roman (1983), the average biochemical composition of phytoplankton, in terms of ash-free dry weight, is taken to be 3 parts protein, 0.6 parts polar lipid, 0.4 parts neutral lipid, and 2.5 parts carbohydrate. Conversions of the amount of ingested constituents $\left(\mathrm{mg} \mathrm{d}^{-1}\right)$ to energy $\left(\mathrm{J} \mathrm{d}^{-1}\right)$ are taken from the literature (Brody 1945, Clarke 1980) and are defined to be $39.55,23.65$, and $17.16 \mathrm{~J} \mathrm{mg}^{-1}$ for lipids, protein, and carbohydrates, respectively.

For the reference simulation and simulations of the sensitivity analysis, phytoplankton food is assumed to be high in austral summer (maximum of $2 \mathrm{mg}$ chl a $\mathrm{m}^{-3}$ ), decreasing to zero in austral winter and increasing towards summer again. Food concentrations follow a seasonal cycle resembling a cosine curve over the course of a year (Fig. 2A) that corresponds to the seasonal cycle of the light regime at $65^{\circ} \mathrm{S}$ during one year. The rationale behind choosing such a food time series is that phytoplankton production varies with light. A maximum chl a value of $2 \mathrm{mg} \mathrm{m}^{-3}$ is chosen because mean phytoplankton mass observed west of the Antarctic Peninsula in summer months is relatively high (>1 $\mathrm{mg} \mathrm{chl} \mathrm{a} \mathrm{m}^{-3}$ ) down to $100 \mathrm{~m}$ (Smith et al. 1996), and in the Scotia Sea it is usually $<2.5 \mathrm{mg} \mathrm{chl} a$ $\mathrm{m}^{-3}$ (Rönner et al. 1983, Jaques 1989, Tréguer \& Jaques 1992). The chl a concentration of the food time series is converted to dry mass phytoplankton by assuming a carbon to chl a ratio of 50; this is at the lower end of the range of 50 to 80 given by Hewes et al. (1990) for autotrophs in regions where chl $a>1 \mathrm{mg} \mathrm{m}^{-3}$, which is close to the average value 47 calculated by Cota et al. (1992) for high latitude phytoplankton in the Scotia Sea.

Sea ice algae provides an additional food source for krill (Marschall 1988, Daly \& Macaulay 1991, Daly 2004) and is thought to be important in relation to the krill life cycle (Kawaguchi et al. 2007). Therefore, an additional phytoplankton food source representing ice algae available in sea ice from August to November (0

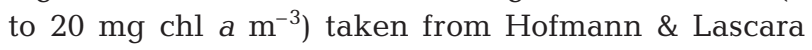
(2000) was included in the model to facilitate the possibility of krill feeding during winter (Fig. 2A). This time
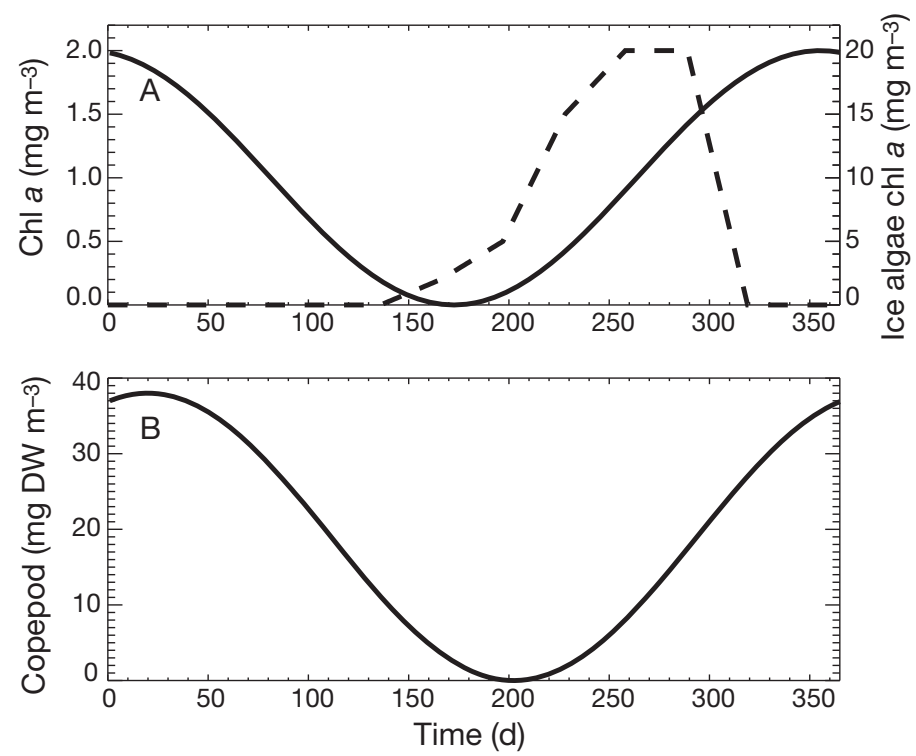

Fig. 2. Food concentrations input into the biochemical model: (A) Phytoplankton chlorophyll a ( $\mathrm{chl}$ a) concentration (solid line) and sea ice algae chl a concentration (dashed line).

(B) Copepod concentration 
series was constructed using data available from Kottmeier \& Sullivan (1987), Stretch et al. (1988), Garrison \& Buck (1989), and Smith \& Sakshaug (1990). It is asymmetric in shape to account for the extended time needed for ice development and the rapid break-up of sea ice in spring (Parkinson 1992, Jacobs \& Comiso 1997) that may seed water column phytoplankton blooms.

Copepods, such as Metridia gerlachei, Oithona similis, and Oncaea curvata have been found in krill stomachs (Nordhausen et al. 1992), and Pakhomov et al. (1997) suggest that krill feed on copepods outside of phytoplankton bloom conditions. Atkinson \& Snÿder (1997) and Atkinson et al. (1999) found this to be true for the South Georgia region, where krill have an important predation impact on copepods. They found that during feeding experiments krill fed rapidly on 1 to $3 \mathrm{~mm}$ calanoid copepods, as well as on Calanoides acutus and Rhincalanus gigas. The copepod food provided to krill in the model is assumed to be C. acutus, a dominant copepod in the South Georgia region (Atkinson et al. 2001). C. acutus average biochemical composition in terms of ash-free dry weight is taken to be 2.8 parts protein, 0.3 parts polar lipid, 1.7 parts neutral lipid, 0.1 parts carbohydrate, and 0.3 parts chitin according to winter observations by Donnelly et al. (1994) and Kattner et al. (1994). However, C. acutus accumulates lipid reserves at the end of summer, preparing for diapause (Kattner et al. 1994, Lee et al. 2006). Therefore, this seasonal change in lipid content is included in the model by having the copepod composition increase in January to 3.1 parts protein, 0.4 parts polar lipid, 2.7 parts neutral lipid, 0.1 parts carbohydrate, and 0.2 parts chitin according to fall measurements by Donnelly et al. (1994), Kattner et al. (1994) and Falk-Petersen et al. (1999), staying at these values until June when they return to the low lipid values measured by Donnelly et al. (1994) and Hagen et al. (1999).

Part of the life cycle of Calanoides acutus is that after laying down intensive lipid stores they gradually descend down to depths $>500 \mathrm{~m}$ to overwinter in diapause, which may move this high lipid food out of the range of krill living in the upper water column; however, krill feed on a large variety of copepods, among them Rhincalanus gigas, Metridia gerlachii and Oithona species, which all remain in the surface layer year round and show seasonal lipid dynamics to different extents (Hagen \& Schnack-Schiel 1996, Atkinson 1998). We, therefore, assume in this modeling study that krill is able to feed on copepods as an alternative food source all year round.

A maximum copepod concentration of $36 \mathrm{mg}$ DW $\mathrm{m}^{-3}$ is assumed over the seasonal cycle, which is within the range of the estimated copepod biomass of $7.5 \mathrm{mg}$
DW $\mathrm{m}^{-3}$ in the Eastern Weddell Sea (Voronina et al. 1994) and the very high concentrations of $65 \mathrm{mg} \mathrm{DW}$ $\mathrm{m}^{-3}$ at South Georgia (Ward et al. 1995). Copepod food is assumed to follow the same seasonal cycle as the phytoplankton food described above, but with a time lag of $20 \mathrm{~d}$ (Fig. 2B) to allow copepods time to respond to the available phytoplankton food. Calanoides acutus has a generation time of approximately $60 \mathrm{~d}$ (Atkinson 1998), and a response of copepods to rising phytoplankton concentrations may be considered a slow process. However, Boyd et al. (1996) described the rapid response of only a few days by zooplankton to an iron-induced phytoplankton bloom in the northeast subantarctic Pacific through migration of copepods into the area and retention mechanisms. Jansen et al. (2006) found that during the European iron fertilization experiment (EIFEX) in the Atlantic Sector of the Southern Ocean Rhincalanus gigas took at most 1 wk to respond to increased food conditions, completed gonad development within this time span, and started spawning. Henjes et al. (2007) suggest that small copepods may react even faster. Therefore, a time lag of $20 \mathrm{~d}$ was chosen for the model food input as a conservative estimate of the ability of copepods to respond to increases in phytoplankton.

\section{RESULTS}

\section{Reference simulation}

The reference simulation was run with optimal phytoplankton food conditions in summer starting January 1 (Day 1), and results are shown for different sizes of krill $(8,22$ and $40 \mathrm{~mm})$ that were chosen to represent larval, juvenile and adult krill (Fig. 3A). Food concentrations are high in January, and all krill grow in size over the first $115 \mathrm{~d}$ (Fig. 3B) until food concentrations fall below $0.4 \mathrm{mg} \mathrm{m}^{-3}$. Then adult and juvenile krill stay at their acquired size for about 20 d, larval krill for about $10 \mathrm{~d}$, after which all krill start shrinking in size until Day 215. After this day, growth resumes while phytoplankton concentrations are at $0.25 \mathrm{mg} \mathrm{m}^{-3}$ and continue to increase.

All sizes of krill show the same seasonal growth pattern, but adult krill grow $12 \mathrm{~mm}$ over the whole year, while juveniles grow $14.4 \mathrm{~mm}$ and larvae grow $19.7 \mathrm{~mm}$. The difference in total growth results from the different metabolic needs of these krill stages (Fig. 3B). Larval krill have the highest growth rates in times of high food supply and reach the maximum growth rate for larvae, $0.16 \mathrm{~mm} \mathrm{~d}^{-1}$, for $13 \mathrm{~d}$ in January. Juveniles stay well below their maximum growth rate of $0.15 \mathrm{~mm} \mathrm{~d}^{-1}$ throughout the simulation, while adult krill grow at their maximum growth rate, i.e. 

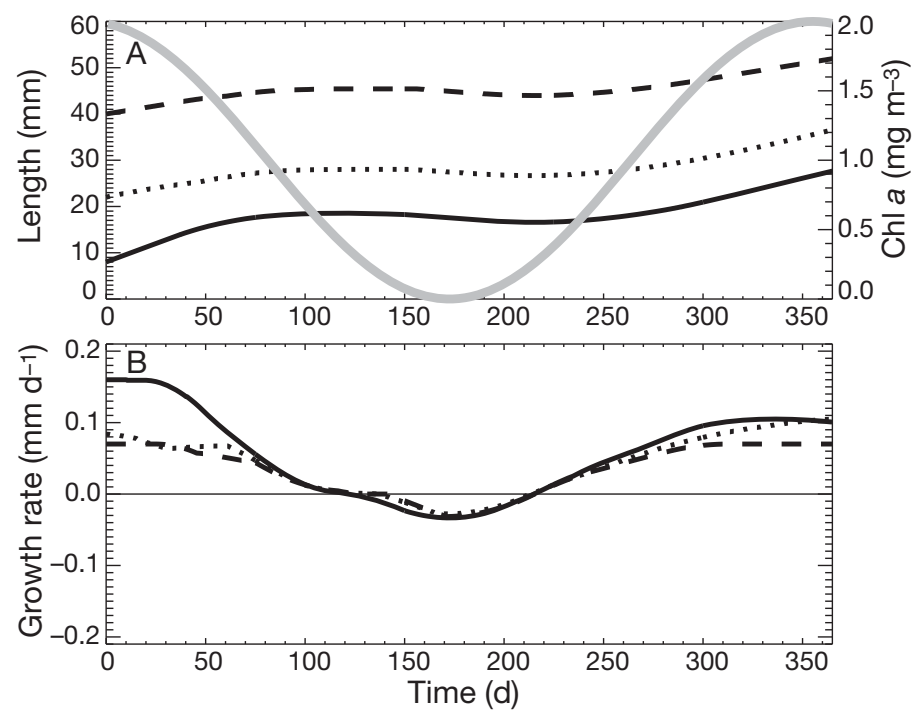

Fig. 3. Euphausia superba. Simulated growth of larval, juvenile, and adult krill over the course of 1 yr under phytoplankton food conditions starting on January 1. (A) Change in larval $(-)$, juvenile $(\cdot$.$) and adult krill (-\mathbf{-})$ length and in phytoplankton concentration (-). (B) Daily growth rates

$0.07 \mathrm{~mm} \mathrm{~d}^{-1}$, for much of the austral summer. Adults would show growth rates up to $0.12 \mathrm{~mm} \mathrm{~d}^{-1}$ (not shown here) if the model did not define a maximum growth rate.

Adult and juvenile krill experience a period of $25 \mathrm{~d}$, larval krill of $10 \mathrm{~d}$, with zero growth rates (Fig. 3B). During this time, food concentrations are below $0.4 \mathrm{mg}$ $\mathrm{m}^{-3}$ (Fig. 3A) and metabolic needs are covered by internal energy supply through lipid metabolism. After this period all krill start shrinking in size for a period of $70 \mathrm{~d}$ using body protein as an energy supply. However, shrinking rates are rather low, less than $0.033 \mathrm{~mm} \mathrm{~d}^{-1}$.

For validation of the model, available lipid data that was not used to parameterize the model is compared to the simulated lipid content of different krill sizes (Fig. 4). The model-data comparison for the reference simulation shows that the model reproduces field data for larvae, juvenile and adult krill under good food conditions (Fig. 4). The range of lipid content of each krill size is within the range of field data. However, the mean total lipid content of simulated krill is low compared to the data.

\section{Sensitivity analysis}

In order to study the sensitivity of the model to changing model parame- ters a sensitivity analysis was done for adult krill (40 mm) using the model set-up of the reference simulation. Each parameter was changed within a range indicated by the literature values, and their percent change in dry weight was recorded (Table 1). Percent change in dry weight was chosen as a sensitive result because it can also be used as a measure for the fitness of krill.

The most important model parameter to which the model is sensitive is the $\mu_{\max }$ for adult krill: a $42 \%$ decrease in $\mu_{\max }$ results in a $22 \%$ decrease in krill dry weight whereas a $42 \%$ increase in $\mu_{\max }$ leads to a $13 \%$ increase in krill dry weight. As expected, krill dry weight is affected directly by limiting how much krill can grow. Note that excess energy that cannot be converted to growth is not lost but is converted into neutral lipid storage and krill that grow more accumulate fewer lipids for storage.

The model is also sensitive to the time krill spends feeding: a decrease and increase in time of $10 \%$ results in $\mathrm{a}-10$ and $+10 \%$ change in krill dry weight, respectively. This parameter regulates how much krill can ingest; therefore, a decrease directly produces a decrease in neutral lipid stores accumulated, opposite to the effect of changes in growth rate. The minimum neutral lipid to polar lipid ratio that can be reached by respiration processes has some influence on model results. Allowing more neutral lipids to be used in respiration increases krill dry weight by $7.5 \%$, because instead of shrinking in size krill can use more storage lipids to balance respiration needs. The effect of decreasing neutral lipids to be used only decreases krill dry weight by $2.1 \%$.

Reducing the assimilation efficiency of protein and polar lipids by $20 \%$ decreases krill dry weight by $7 \%$ and has considerably more influence on model outcome than changes in carbohydrate and neutral lipid assimilation efficiencies. Of the ratios between the

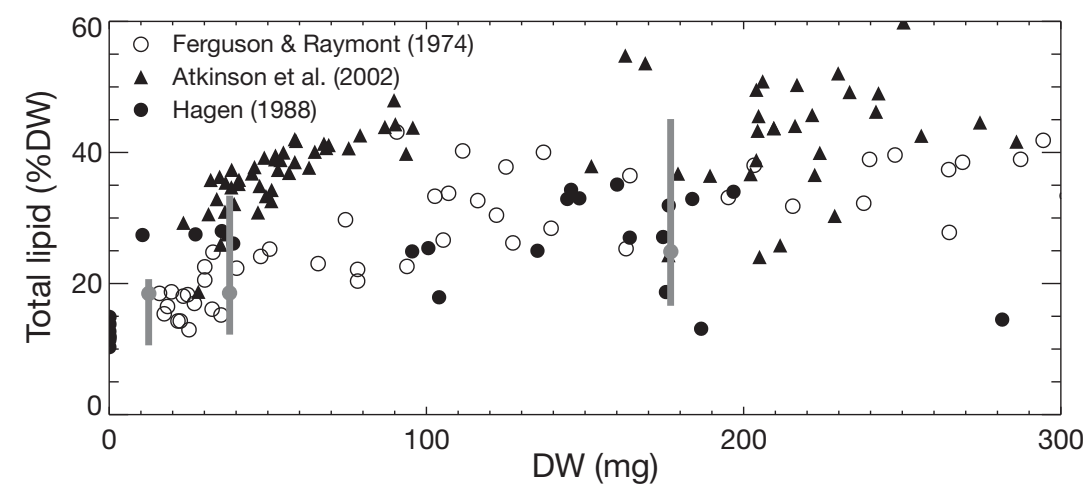

Fig. 4. Euphausia superba. Total lipid (\%DW) concentration as a function of krill dry weight. Gray circles: mean total lipid values; gray lines: range of values simulated in the model 
chemical compartments which are calculated from Eqs. (6) to (10) only the protein to ash and polar lipid to protein ratios influence model outcome somewhat (Table 1). The effect of all other ratios is negligible.

Another important parameter to which the model is sensitive is the ratio of carbon to chl $a, \mathrm{C}: \mathrm{chl} a$ ( $50 \mathrm{mg} \mathrm{C}$ (mg chl a $)^{-1}$ in the reference case), that is applied to model input files of chl a concentration. A range of -50 to $+29 \%$ in krill dry weight results from the choice of varying the carbon to chl a ratio for phytoplankton from 40 to $60 \mathrm{mg} \mathrm{m}^{-3} \mathrm{C}\left(\mathrm{mg} \mathrm{m}^{-3} \mathrm{chl} a\right)^{-1}$.
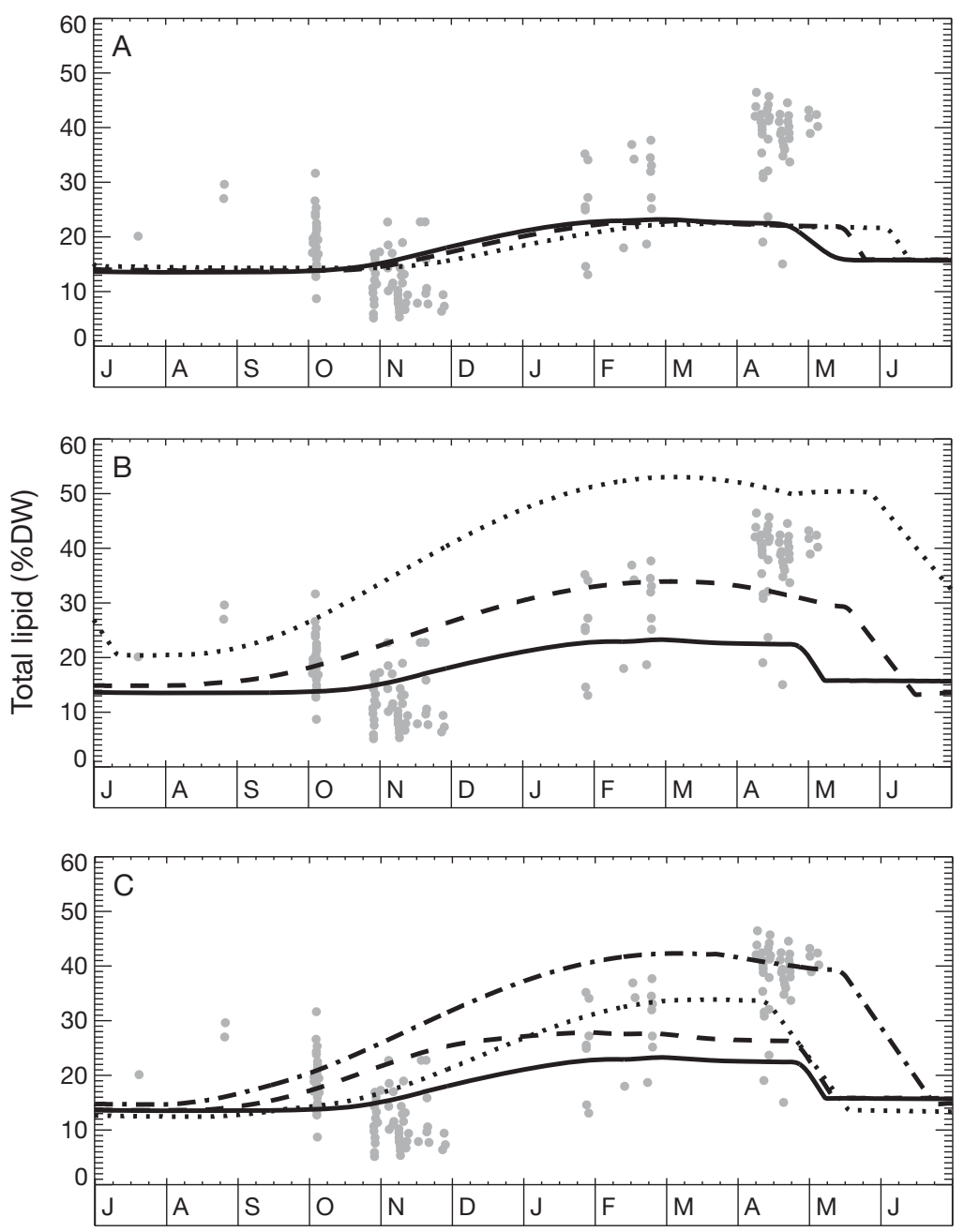

Time (mo)

Fig. 5. Euphausia superba. Simulated seasonal lipid content of adult krill feeding on the following: (A) phytoplankton as shown in Fig. 2A (reference simulation, black line) or when phytoplankton food is moved to start $10 \mathrm{~d}$ later (dashed line) or $30 \mathrm{~d}$ later (dotted line); (B) reference simulation as in

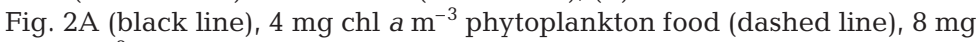
chl a m ${ }^{-3}$ phytoplankton food (dotted line); (C) reference simulation as in Fig. 2A (black line), both phytoplankton and sea ice algae food as in Fig. 2A (dashed line), copepod food as in Fig. 2B (dotted line) and copepod food and phytoplankton together (dashed-dotted line)

\section{Effect of diet}

Another factor indicating fitness of krill besides growth is krill lipid content. The model-data comparison above already indicated that krill in the model have low lipid content compared to observations (Fig. 4), but to explore this issue further the total lipid content of adult krill is tracked over 2 yr of the reference simulation and plotted from one winter to the next (July to June) (Fig. 5).

Total lipid content of adult krill (Fig. 5A, solid line) experiencing food concentrations of the reference simulation (Fig. 2A) is low, at $14 \%$, from July to October and increases to maximum levels of $24 \%$ by mid-February. This increase lags behind the increase in food concentrations above $0.4 \mathrm{mg} \mathrm{m}^{-3}$ by about $1.5 \mathrm{mo}$. In April, when food concentration falls below $0.4 \mathrm{mg} \mathrm{m}^{-3}$ and krill growth rate reaches zero (Fig. 3B), total lipid concentrations fall to $16 \%$ within $25 \mathrm{~d}$ and then stay at this level.

Observations of the seasonal cycle of adult krill (Hagen et al. 1996, 2001, FalkPetersen et al. 2000) show low lipid concentrations (5 to $25 \%$ ) in October and November and increasing lipid values until April (30 to $45 \%$ ) that decrease again towards October (Fig. 5, gray dots). To explore the timing of seasonal lipid variations the reference food time series was moved to start $10 \mathrm{~d}$ (Fig. 5A, dashed line) and $30 \mathrm{~d}$ (Fig. 5A, dotted line) later, resulting in lipid cycles 10 and $30 \mathrm{~d}$ moved back in time from the reference simulation, respectively. Therefore, the timing of food availability determines the seasonal timing of lipid increase and decrease during the seasonal cycle of lipid variations in modeled krill.

Additional simulations were done to evaluate if higher phytoplankton food concentrations have an influence on the maximum lipid values in the seasonal lipid cycle of krill (Fig. 5B). Phytoplankton food time series with maximum values of 4 and $8 \mathrm{mg}$ $\mathrm{m}^{-3}$ and the same seasonal pattern as the reference food time series (Fig. 2A) were input to the model. Doubling the phytoplankton concentration results in slightly higher lipid concentrations (15\%) in winter and an increase to almost $34 \%$ in late summer (Fig. 5B, dashed line). These results range within the observed lipid concentrations in January and February but are be- 
low the high values observed in August (Fig. 5B, dashed line). In addition, the drawdown of lipids in winter starts at the end of May. Quadrupling the phytoplankton concentration results in lipid values of $52 \%$ in late summer and in winter the lipid concentrations are rather high at $20 \%$ (Fig. 5B, dotted line). These are the maximum lipid values that krill can reach with phytoplankton food, because krill reaches its daily ration limitation, which ensures that krill cannot feed on more than $10 \%$ of its own body carbon weight.

To test the influence of sea ice algae food that may be available to krill during winter, a further simulation used the reference phytoplankton time series together with the sea ice algae time series (Fig. 2A). Being able to utilize this additional food source results in an increase in total lipid starting in August and maximum total lipid values of up to $28 \%$ (Fig. 5C, dashed line). High lipid values are reached 3 mo earlier than when krill are feeding on phytoplankton only and, as in the reference simulation, total lipid concentrations fall to $16 \%$ within 1 mo in April/May at the onset of winter.

The effect of lipid-rich heterotrophic food on seasonal lipid dynamics of adult krill was tested by having krill in the model feed on the copepod time series (Fig. 2B). The effect of this food (Fig. 5C, dotted line) is remarkable in that it produces maximum total lipid values of $35 \%$ in adult krill in May and also produces a drawdown of lipids in winter, reaching a low of $12.5 \%$ in August and September. These results match observed lipid concentrations from January to April but fail to produce the very high observed lipid concentrations in April/May. Instead the low observed lipid values in October/November are reproduced.

Assuming that both phytoplankton food and copepod food (Fig. 2) are available for krill in the field, a last simulation tested the effect of this food combination (Fig. 5C, dash-dotted line). As expected, this simulation produces the highest lipid concentrations in summer $(42 \%)$, agreeing with observations in April/May. However, in this simulation observations of low lipid content in October/November are not reproduced. Krill in this simulation is able to accumulate up to $7 \%$ more lipids than observed.

\section{Effect of overwintering strategies}

Further simulations with the model under reference simulation conditions, but without any food input, show that krill survives starvation for 72 to $212 \mathrm{~d}$, survival times increasing with the size of the individual (Fig. 6). When the strategy of $50 \%$ metabolic rate reduction in winter is turned off, survival times decrease by an average of $30 \mathrm{~d}$ and by 14 and $10 \mathrm{~d}$ in 10 and $60 \mathrm{~mm}$ krill, respectively. Turning off lipid utiliza-

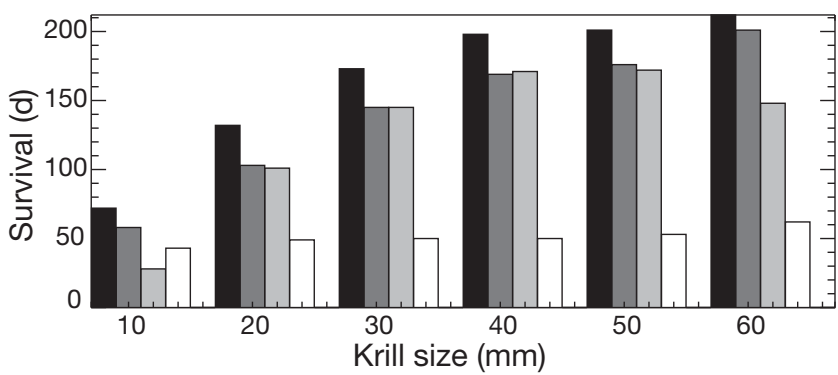

Fig. 6. Euphausia superba. Model results of krill survival under starving conditions versus krill size. Black bars: survival using all 3 strategies; dark gray bars: survival without reduction of metabolic rates in winter; light gray bars: survival without lipid utilization; white bars: survival without combustion of body components

tion instead of metabolic rate reduction reduces survival by amounts similar to those for reduction in metabolism. An exception is larval krill, where turning off this strategy results in survival of only $28 \mathrm{~d}$. In a further simulation the use of body structure together with body shrinkage is turned off. This overwintering strategy allows krill to use up to $45 \%$ of their body dry weight to meet energy demands. Not being able to do so results in krill larvae surviving $43 \mathrm{~d}$ and adults surviving $62 \mathrm{~d}$ without food. Survival time increases slightly with krill size.

\section{DISCUSSION}

\section{Model performance}

With the development of this model a first attempt was made to simulate complicated krill metabolism with a relatively simple depiction of biochemistry within Antarctic krill. Relationships between biochemical compartments in the model were calculated using data sets of observations and laboratory studies on krill caught at locations separated in space (e.g. Scotia Sea vs. Lazarev Sea) and time, which causes large discrepancies between data. We are aware that this may alter the parameters and equations used in the model and with it model results. However, with so little data available on krill biochemistry it was necessary to combine all data sets in this manner.

The growth rates produced by the model without defining any restrictions such as maximum growth rates for different krill stages are $0.12 \mathrm{~mm} \mathrm{~d}^{-1}$ for adult krill, $0.09 \mathrm{~mm} \mathrm{~d}^{-1}$ for juveniles and $0.2 \mathrm{~mm} \mathrm{~d}^{-1}$ for larval krill. These values, although lower than in the Fach et al. (2002) krill growth model, are well within the range of observed growth rates, e.g. 0.105 to $0.179 \mathrm{~mm}$ $\mathrm{d}^{-1}$ (Rosenberg et al. 1986) and $0.33 \mathrm{~mm} \mathrm{~d}^{-1}$ (Clarke \& Morris 1983), but are slightly higher than values sum- 
marized by Siegel \& Nicol (2000). This indicates that the model is capable of reproducing realistic growth of krill, including the observation that larval krill have the highest growth rates.

Maximum model growth rates were defined using the values summarized by Siegel \& Nicol (2000) to indirectly account for the fact that adult females do not grow much in size but rather increase their lipid reserves for reproduction (Kawaguchi et al. 2006). Hagen (1988) suggested that young krill convert food mainly into muscle tissue (protein) while adult krill also use it to produce gonads and to accumulate storage lipids. Defining a maximum growth rate for krill in the model translates into krill converting more energy into lipid storage than into growth. However, parameterization for the energy costs of reproduction is not included in the model at this stage but will be included in future modeling efforts.

Food concentrations decreasing to below $0.5 \mathrm{mg}$ chl $a^{-3}$ in fall are not enough to meet krill respiration needs and force krill in the model to start using up internal lipid stores. When all available lipid reserves have been utilized, krill in the model starts shrinking. Maximum shrinking rates of adult krill do not exceed $0.033 \mathrm{~mm} \mathrm{~d}^{-1}$ over $70 \mathrm{~d}$, accumulating to a total reduction of $1.44 \mathrm{~mm}$ length during that period. Assuming that krill moults every 20 to 30 d (Quetin \& Ross 1991), krill may moult 2 times during this period, decreasing $0.72 \mathrm{~mm}$ in size at each moult. This shrinking rate is within values of $2 \%$ body length per moult calculated by Quetin \& Ross (1991).

In the process of establishing the model it became apparent that important data on lipid metabolism are not available. In addition to smaller amounts of phospholipid, krill mainly accumulates triacylglycerols as a storage lipid during times of high food supply when krill lipid levels increase (Hagen et al. 1996). However, as yet it is not known which of the lipid reserves (neutral or polar lipid) is utilized by different stages of krill in situations of starvation. Therefore, the model defines polar lipid and neutral lipid pools separately, and neutral lipids, representing storage lipids, are utilized first during starvation. The model was designed this way because neutral lipids are known to deliver high amounts of energy per mass and are more easily mobilized than polar lipids (Hagen 1996). Polar lipid is only depleted in the model when krill is shrinking. This approach was used for simplicity although it has been shown that Euphausia superba may accumulate certain polar lipids as storage lipids as well (Saether et al. 1985, Hagen 1988, Hagen et al. 1996). Nevertheless, the model accounts for polar lipid to neutral lipid ratios within the range of observations (Hagen 1988) and minimum total lipid values in winter that match observations (Hagen et al. 1996, 2001).
Results from the sensitivity study point to the fact that using carbon to chl a ratios to convert phytoplankton chl a concentrations that are an input to the model to phytoplankton carbon is problematic. The model is sensitive to this factor because it influences the quantity of food that is input into the model, which indirectly affects the growth rate of krill. Reducing this factor reduces the food available to krill in the model, which may cause krill to starve and shrink in size. That explains why reducing the factor has a larger impact than increasing it.

Determining the carbon to chl a ratio is difficult as this ratio is not only time dependent (Banse 1977) but also varies significantly with season and species assemblage (Smith \& Nelson 1985, Smith \& Sakshaug 1990, Villafañe et al. 1993, Smith et al. 2000, Garibotti et al. 2003). The great imprecision of estimations of this ratio has already been pointed out by Strickland (1960) and Banse (1977), and to date not many estimates exist for Antarctic phytoplankton. Many models and also the calculation of the generation times of phytoplankton or daily rations of zooplankton for field situations greatly depend on the correct definition of this ratio. This points to the need for better estimations of the carbon to chl a ratio, or better, direct measurements of the phytoplankton carbon content. However, in the model setup presented here, as well as when satellite data of phytoplankton concentration are used, there is currently no way around using carbon to chl a ratios.

\section{Lipid metabolism}

Mean total lipid content of simulated adult krill in the reference simulation is low compared to data from the literature, indicating that while adult krill achieves observed growth rates, it cannot accumulate as much lipid as observed in the field (Hagen et al. 1996, 2001, Falk-Petersen et al. 2000) on phytoplankton food alone. At the same time high larval growth rates indicate that larvae have fewer lipid reserves than juveniles and adults, which fits observations (Hagen et al. 1996, 2001, Falk-Petersen et al. 2000).

The simulated seasonal cycle of lipid variation in adults is similar to the observations made by Hagen et al. $(1996,2001)$ and reviewed by Falk-Petersen et al. (2000), with low lipid concentrations in spring and a strong increase in lipid values until fall. Lipid concentrations of adult krill in austral spring in the model are well within the observed range. However, the simulated high lipid values in summer $(24 \%)$ are almost half the value observed by Hagen et al. (1996, 2001). Although Hagen et al. $(1996,2001)$ report a few observations that have lipid values around $24 \%$ in summer, most data show significantly higher total lipid con- 
centrations. This is concerning, especially when considering that this model does not include any parameterizations for reproduction, a developmental feature requiring additional lipid reserves.

Only very high amounts of phytoplankton food (8 mg $\mathrm{m}^{-3}$ ) can produce observed lipid values in summer. However, the food time series used in the model represents an environment where phytoplankton concentrations are available over long periods of time and does not take the strong variability in phytoplankton concentrations in the Southern Ocean (Murphy et al. 1998) into account. Satellite images of the Southern Ocean show variable patches of high phytoplankton concentrations up to $10 \mathrm{mg} \mathrm{m}^{-3}$ in some regions such as in the Scotia Sea (Atkinson et al. 2001), but a constant supply of such high food amounts as used here is rather unrealistic, as data extracted from satellite data in the Scotia Sea shows (Fach et al. 2002, 2006).

Including sea ice algae as a winter food source makes a more realistic simulation and results in increased summer lipid levels that are 3\% higher than with phytoplankton food alone. Because of earlier availability of this food to krill in the model, krill are able to increase its depleted lipid reserves almost 2 mo earlier than in the reference simulation. Therefore, the inclusion of this additional food source may benefit adult krill at the end of winter, when krill are able to increase lipid stores earlier than when feeding on phytoplankton only. However, overall the inclusion of ice algae does not increase adult lipid content much, indicating that it is of minor importance, which agrees with results from previous modeling efforts (Fach et al. 2002, 2006).

It becomes apparent in the present study that lipidrich food produces simulated summer lipid content of adult krill comparable to observations. Feeding on copepods when phytoplankton is also available produces maximum total lipid values of $42 \%$ in krill in May, which is consistent with observations by Hagen et al. (2001) and Atkinson et al. (2002). It can, therefore, be concluded that the high lipid levels observed in adult krill may actually be accumulated through feeding on food sources other than phytoplankton which are available to krill such as ice algae or, more importantly, copepods. In fact, the simulation results support the possibility that heterotrophic food (carnivory) may be fundamental to the energy intake of adult krill, even during periods when phytoplankton is available, as has been suggested by Price et al. (1988), Granéli et al. (1993), and Perissinotto et al. (2000).

One important phenomenon in the lipid metabolism of krill is the possibility of de novo biosynthesis of lipid (as fatty acids) from dietary carbohydrate and protein. Copepods (Sargent et al. 1976, Sargent \& Henderson 1986) and euphausiids (Henderson et al. 1981, 1982,
Scott et al. 2002) have been shown to be capable of using de novo biosynthesis, and Clarke (1980) suggests that Antarctic krill acquires ovarian triacylglycerols largely from de novo synthesis. Individual Thysanoessa inermis were shown to be capable of synthesizing approximately $0.1 \mathrm{mg}$ lipid as fatty acids de novo per day at $5^{\circ} \mathrm{C}$ (Henderson et al. 1981). Henderson et al. (1982) showed that such biosynthesis in the high latitude euphausid $T$. raschi may be up to 3 times faster than in T. inermis, which lives in lower latitudes. While krill in the model are able to synthesize lipids de novo, this process only produces limited amounts of lipids in the current model set up. Allowing extensive lipid biosynthesis such as observed for T. inermis in the krill model may increase the amount of lipids that can be accumulated by krill on a phytoplankton diet and could relativize the need for the lipid-rich food discussed above.

The seasonality of the lipid cycle in the model is due in part to the reduction of metabolic rates in wintertime that coincides with a reduction in light levels (Hofmann \& Lascara 2000), but mainly because of the imposed seasonal cycle of food concentrations (Fig. 5B). Teschke et al. (2007) found an important influence of the environmental light regime on physiological parameters of krill in laboratory studies, not only on the metabolic rate of krill but also on the ingestion rate and daily rations. This agrees with observations of Atkinson et al. (2002) and indicates that these parameters should be linked to a seasonal cycle in future models.

\section{Overwintering strategies}

Simulating prolonged starvation with the model shows survival times of 72 to 212 d for 10 to $60 \mathrm{~mm}$ krill, indicating longer survival times for larger individuals. This trend matches data showing that adult krill can survive between 150 to 210 d (Ikeda \& Dixon 1982, Atkinson et al. 2002) and shows that juvenile and adult krill in the model are well prepared to survive long winters without food.

Looking at the influence of different overwintering strategies in the model, it can be concluded that shrinking in size and use of body reserves plays a major role in survival during times of low food supply for adult krill, as has been suggested by Ikeda \& Dixon (1982). Krill in the model are allowed to shrink and lose up to $45 \%$ of their body weight according to measurements made by Ikeda \& Dixon (1982). This strategy alone explains $28 \mathrm{~d}$ of krill survival for larvae, $83 \mathrm{~d}$ for juveniles, and 123 to $150 \mathrm{~d}$ for adult krill. Or expressed differently, use of body structure to meet energy demands is the greatest source of energy for krill in the 
model. It should be noted that use of body protein also depletes the polar lipid and carbohydrate content of krill, as body structure is composed of all 3 components. This fits well with detailed calculations by Torres et al. (1994), who estimate 122 and $151 \mathrm{~d}$ of survival with this overwintering strategy for 30 and $50 \mathrm{~mm}$ krill, respectively. However, this importance of shrinking contrasts with calculations by Quetin \& Ross (1991), who propose that metabolic rate reduction contributes $71 \%$, lipid utilization $11 \%$, and shrinkage $4 \%$ of the energy requirement of adults in winter.

The reduction of krill metabolism by $50 \%$ in winter is less important than lipid utilization for adults in this model. However, krill larvae have been shown not to reduce their metabolism during fall (Meyer et al. 2002), and model results may support this observation. If larval krill were to reduce their metabolic rates, they would survive $14 \mathrm{~d}$ longer, which indicates that this strategy is the least effective of all for larval krill in the model.

Model results show that extensive lipid utilization alone does not have a high impact on krill survival. Turning off this strategy reduces survival by amounts similar to those caused by reduction in metabolism and therefore is not effective in helping krill through the winter. This is in contrast to calculations by Hagen et al. (2001) and Atkinson et al. (2002), who conclude that lipid reserves are sufficient to do so. However, our model results support the studies of Virtue et al. (1997), who show that lipid is an important energy source during short-term starvation but that in the long term lipid reserves are essentially being conserved. They suggest that lipid in Antarctic krill is used primarily for reproduction rather than as an overwintering energy source. Studies of boreal euphausiids (Falk-Petersen et al. 1981) similarly conclude that lipid is more important for gonad formation than for the maintenance of basal metabolism during overwintering. It should be noted further that the model defines lipid utilization as the use of neutral lipid storage reserves only, while the calculations done by Hagen et al. (2001) and Atkinson et al. (2002) assumed utilization of all forms of lipid. Further studies on which lipid reserve (polar or neutral lipid) is utilized by different stages of krill in starving situations will help to better define lipid metabolism in the model.

In addition, the survival time of krill is also a function of the amount of lipids stored in krill before starving, which has been shown to be low in krill in the model. As discussed above, phytoplankton alone is not sufficient to induce the observed lipid content of krill of all stages over most of the year in this model. This may be due in part because only very limited biosynthesis of lipids de novo is allowed in the model and may be less of an issue once this mechanism is included. As a result, krill in the model needs to feed on substantial amounts of lipid-rich food, such as copepods, to accumulate their observed lipid content in summer. When krill is able to feed on lipid-rich food before starvation, the strategy of lipid utilization increases significantly in importance, which has also been shown by Torres et al. (1994).

\section{Future model refinements}

An important process of krill life history missing in this biochemical model is reproduction. Krill reproduction requires different energetic efforts for male and female krill (Clarke 1980). Spent females and males have the lowest lipid levels, with females losing half their body lipids at spawning. Highest lipid levels were found in gravid females, and their lipid-rich gonads contained $61 \%$ of all the females' lipids (Hagen et al. 2001). Nicol et al. (1995) showed that Antarctic krill females lose one-third of their body mass during a single spawning. Considering the growing evidence of multiple spawning during one summer (Quetin et al. 1994), the reproductive effort of females is substantial and should be considered in future modeling studies.

Torres et al. (1994) show clearly that there are large differences in mean krill lipid content during fall and winter, depending on time and location of capture. They observed the same phenomenon for protein levels but on smaller scales. They concluded that while some of the lipid variations in fall may be ascribed to reproductive activity, some may be attributed to differences in lipid utilization or to differences in lipid levels present in krill before entering the winter season. Such inherent differences cannot be modeled with an individual-based model such as the one presented here. However, this could be accounted for when a whole krill population including inherent genetic differences is modeled, such as has been done for oyster larvae (Bochenek et al. 2001)

Developing the model used in the present study was a first attempt to simulate complicated krill metabolism with a relatively simple depiction of biochemistry within Antarctic krill. This model works well even though only limited biochemical processes are included and provides a valuable tool for simulating the effect of different diet and overwintering strategies on krill. With further improvements of the model such as refining lipid biosynthesis, including reproductive processes and increasing the model to the population level, this type of biochemical model of krill may have the potential to investigate environmental and biological factors controlling population dynamics of Antarctic krill. 
Acknowledgements. The authors thank J. Torres, who made valuable krill data sets available for use in the model. We also thank E. E. Hofmann for extensive discussions on krill modeling. Two anonymous reviewers helped to improve the mansucript. This research was supported by the German National Science Foundation (DFG) grant number FA-475/1-1. The computer facilities and resources used were provided by the Alfred Wegener Institute for Polar and Marine Research.

\section{LITERATURE CITED}

Atkinson A (1998) Life cycle strategies of epipelagic copepods in the Southern Ocean. J Mar Syst 15:289-311

Atkinson A, Snÿder R (1997) Krill-copepod interactions at South Georgia, Antarctica, I. Omnivory by Euphausia superba. Mar Ecol Prog Ser 160:63-76

Atkinson A, Ward P, Hill A, Brierley AS, Cripps GC (1999) Krill-copepod interactions at South Georgia, Antarctica, II. Euphausia superba as a major control on copepod abundance. Mar Ecol Prog Ser 176:63-79

Atkinson A, Whitehouse MJ, Priddle J, Cripps GC, Ward P, Brandon MA (2001) A productive, cold water pelagic ecosystem: a review of South Georgia, Antarctica. Mar Ecol Prog Ser 216:279-308

Atkinson A, Meyer B, Stübing D, Hagen W, Schmidt K, Bathmann UV (2002) Feeding and energy budgets of Antarctic krill Euphausia superba at the onset of winter: II. Juveniles and adults. Limnol Oceanogr 47:953-966

Atkinson A, Shreeve RS, Hirst AG, Rothery P and others (2006) Natural growth rates in Antarctic krill (Euphausia superba): II. Predictive models based on food, temperature, body length, sex, and maturity stage. Limnol Oceanogr 51:973-987

Banse K (1977) Determining the carbon-to-chlorophyll ratio of natural phytoplankton. Mar Biol 41:199-212

Bochenek EA, Klinck JM, Powell EN, Hofmann EE (2001) A biochemically based model of the growth and development of Crassostera gigas larvae. J Shellfish Res 20: 243-265

Boyd PW, Muggli D, Varela D, Goldblatt RH, Chretien R, Orians KL, Harrison PJ (1996) In vitro iron enrichment experiments in the NE Subantarctic Pacific. Mar Ecol Prog Ser 136:179-193

Brody S (1945) Bioenergetics and growth. Reinhold, New York

Candy SG, Kawaguchi S (2006) Modelling growth of Antarctic krill. II. Novel approach to describing the growth trajectory. Mar Ecol Prog Ser 306:17-30

Clarke A (1976) Some observations on krill (Euphausia superba Dana) maintained alive in the laboratory. $\mathrm{Br}$ Antarct Surv Bull 43:111-118

- Clarke A (1980) The biochemical composition of krill Euphausia superba Dana, from South Georgia. J Exp Mar Biol Ecol 43:221-236

Clarke A, Morris DJ (1983) Towards an energy budget for krill: the physiology and biochemistry of Euphausia superba Dana. Polar Biol 2:69-86

Cota GF, Smith WO, Nelson DM, Muench RD, Gordon LI (1992) Nutrient and biogenic particulate distributions, primary productivity and nitrogen uptake in the WeddellScotia Sea marginal ice zone during winter. J Mar Res 50: 155-181

> Daly KL (2004) Overwintering growth and development of larval Euphausia superba: an interannual comparison under varying environmental conditions west of the Antarctic Peninsula. Deep-Sea Res II 51:2139-2168
Daly KL, Macaulay MC (1991) Influence of physical and biological mesoscale dynamics on the seasonal distribution and behavior of Euphausia superba in the Antarctic marginal ice zone. Mar Ecol Prog Ser 79:37-66

> Donnelly J, Torres JJ, Hopkins TL, Lancraft TM (1994) Chemical composition of Antarctic zooplankton during austral fall and winter. Polar Biol 14:171-183

Fach BA, Klinck JM (2006) Transport of Antarctic krill (Euphausia superba) across the Scotia Sea. Part I: circulation and particle tracking simulations. Deep-Sea Res I 53: 987-1010

Fach BA, Hofmann EE, Murphy EJ (2002) Modeling studies of Antarctic krill Euphausia superba survival during transport across the Scotia Sea. Mar Ecol Prog Ser 231:187-203

Fach BA, Hofmann EE, Murphy EJ (2006) Transport of Antarctic krill (Euphausia superba) across the Scotia Sea. Part II: krill growth and survival. Deep-Sea Res I 53: 1011-1043

Falk-Petersen S, Gatten RR, Sargent JR, Hopkins CCE (1981) Ecological investigationson the zooplankton community in Balsfjorden, northern Norway: seasonal changes in the lipid class composition of Meganyctiphanes norvegica (M. Sars), Thysanoessa rashii (m. Sars), T. inermis (Krøyer). J Exp Mar Biol Ecol 54:209-224

$>$ Falk-Petersen S, Sargent JR, Lonne OL, Timofeev S (1999) Functional biodiversity of lipids in Antarctic zooplankton: Calanoides acutus, Calanus propinquus, Thysanoessa macrura and Euphausia chrystallorophias. Polar Biol 21: $37-47$

Falk-Petersen S, Hagen W, Kattner G, Clarke A, Sargent JR (2000) Lipids, trophic relationships, and biodiversity in Arctic and Antarctic krill. Can J Fish Aquat Sci 57: 178-191

Ferguson CF, Raymont JKB (1974) Biochemical studies on marine zooplankton XII. Further investigations on Euphausia superba Dana. J Mar Biol Assoc UK 54: 719-725

Garibotti IA, Vernet M, Kozlowski WAA, Ferrario ME (2003) Composition and biomass of phytoplankton assemblages in coastal Antarctic waters: a comparison of chemotaxonomic and microscopic analyses. Mar Ecol Prog Ser 247: $27-42$

Garrison DL, Buck KR (1989) Algal assemblages in Antarctic pack ice and in ice-edge plankton. J Phycol 23:564-572

Granéli E, Granéli W, Rabbani MM, Daugbjerg N, Fransz G, Cuzin-Roudy J, Alder VA (1993) The influence of copepod and krill grazing on species composition of phytoplankton communities from the Scotia-Weddell Sea. Polar Biol 13: $201-213$

Hagen W (1988) On the significance of lipids in Antarctic zooplankton. Ber Polarforsch 49:1-129

Hagen W (1996) The role of lipids in the ecology of polar plankton and nekton-a synopsis. Habilitation thesis, Christian-Albrechts-Universität zu Kiel

> Hagen W, Schnack-Schiel SB (1996) Seasonal lipid dynamics in dominant Antarctic copepods: energy for overwintering or reproduction? Deep-Sea Res I 43:139-158

Hagen W, Van Vleet ES, Kattner G (1996) Seasonal lipid storage as overwintering strategy of krill. Mar Ecol Prog Ser 134:85-89

> Hagen W, Kattner G, Terbrüggen A, Van Vleet ES (2001) Lipid metabolism of the Antarctic krill Euphausia superba and its ecological implications. Mar Biol 139:95-104

Hamner WM (1984) Aspects of schooling of Euphausia superba. J Crustac Biol 4:67-74

> Hamner WM, Hamner PP, Strand SW, Gilmer RW (1983) Behavior of Antarctic krill Euphausia superba: chemo- 
reception, feeding, schooling and moulting. Science 220: $433-435$

Handa N (1969) Carbohydrate metabolism in the marine diatom Skeletonema costatum. Mar Biol 4:208-214

> Henderson RJ, Sargent JR, Falk-Petersen S (1981) Lipogenesis in the arctic euphausiid Thysanoessa inermis. Mar Biol 63:235-240

Henderson RJ, Falk-Petersen S, Sargent JR (1982) The composition and biosynthesis of lipids in Thysanoessa raschi from the Clyde Estuary, Scotland. Mar Biol 70:7-12

$>$ Henjes J, Assmy P, Klaas C, Verity P, Smetacek V (2007) Response of microzooplankton (protists and small copepods) to an iron-induced phytoplankton bloom in the Southern Ocean (EisenEx). Deep-Sea Res I 54:363-384

Hewes CD, Sakshaug E, Reid FMH, Holm-Hansen O (1990) Microbial autotrophic and heterotrophic eucaryotes in Antarctic waters: relationships between biomass and chlorophyll, adenosine triphosphate and particulate organic carbon. Mar Ecol Prog Ser 63:27-35

> Hofmann EE, Lascara CM (2000) Modeling the growth dynamics of Antarctic krill Euphausia superba. Mar Ecol Prog Ser 194:219-231

Holm-Hansen O, Huntley M (1984) Feeding requirements of krill in relation to food sources. J Crustac Biol 4(1):156-173

Ikeda T (1984a) Development of the larvae of Antarctic krill (Euphausia superba Dana) in the laboratory. J Exp Mar Biol Ecol 75:107-117

Ikeda T (1984b) Sequences in metabolic rates and elemental composition (C, N, P) during the development of Euphausia superba Dana and estimated food requirement during its life span. J Crustac Biol 4(1):273-284

$>$ Ikeda T, Dixon P (1982) Body shrinkage as a possible overwintering mechanism of the Antarctic krill, Euphausia superba Dana. Aust J Mar Freshw Res 33:71-76

Jacobs SS, Comiso JC (1997) Climate variability in the Admusen and Bellinghausen Seas. J Clim 10:697-709

> Jansen S, Klaas C, Krägefsky S, von Harbou L, Bathmann U (2006) Reproductive response of Rhincalanus gigas to an iron-enriched phytoplankton bloom in the Southern Ocean. Polar Biol 29:1039-1044

Jaques G (1989) Primary production in the open Antarctic Ocean during austral summer. A review. Vie Milieu 39: $1-17$

Kato M, Segawa S, Tanoue E, Murano M (1982) Filtering and ingestion rates of the Antarctic krill Euphausia superba Dana. Trans Tokyo Univ Fish 5:167-175

Kattner G, Graeve M, Hagen W (1994) Ontogenetic and seasonal changes in lipid and fatty acid/alcohol compositions of the dominant Antarctic copepods Calanus propinquus, Calanoides acutus and Rhincalanus gigas. Mar Biol 118: 637-644

Kawaguchi S, Candy SG, King R, Naganobu M, Nicol S (2006) Modelling growth of Antarctic krill. I. Growth trends with sex, length, season, and region. Mar Ecol Prog Ser 306: $1-15$

Kawaguchi S, Yoshida T, Finley L, Cramp P, Nicol S (2007) The krill maturity cycle: a conceptual model of the seasonal cycle in Antarctic krill. Polar Biol 30:689-698

Kottmeier ST, Sullivan CW (1987) Late winter primary productivity and bacterial production in sea ice and seawater west of the Antarctic Peninsula. Mar Ecol Prog Ser 36: 287-298

Lee RF, Nevenzel JC, Paffenhöfer GA (1971) Importance of wax esters and other lipids in the marine food chain: phytoplankton and copepods. Mar Biol 9:99-108

> Lee RF, Hagen W, Kattner G (2006) Lipid storage in marine zooplankton. Mar Ecol Prog Ser 307:273-306
Marschall HP (1988) The overwintering strategy of the Antarctic krill under the pack-ice of the Weddell Sea. Polar Biol 9:129-135

> Meyer B, Oettl B (2005) Effects of short-term starvation on composition and metabolism of larval Antarctic krill Euphausia superba. Mar Ecol Prog Ser 292:263-270

Meyer B, Atkinson A, Stübing D, Oettl A, Hagen W, Bathmann UV (2002) Feeding and energy budgets of Antarctic krill Euphausia superba at the onset of winter-I. Furcilia larvae. Limnol Oceanogr 47:943-952

> Meyer B, Atkinson A, Blume B, Bathmann UV (2003) Feeding and energy budgets of larval Antarctic krill Euphausia superba in summer. Mar Ecol Prog Ser 257:167-177

> Murphy EJ, Watkins JL, Reid K, Trathan PN and others (1998) Interannual variability of the South Georgia marine ecosystem: biological and physical sources of variation in the abundance of krill. Fish Oceanogr 7:381-390

Nicol S, Stolp M, Nordstrom O (1992) Change in the gross biochemistry and mineral content accompanying the moult cycle in the Antarctic krill Euphausia superba. Mar Biol 113:201-209

Nicol S, de la Mare WK, Stolp M (1995) The energetic cost of egg production in Antarctic krill (Euphausia superba Dana). Antarct Sci 7:25-30

Nordhausen W, Huntley M, Lopez MDG (1992) RACER: carnivory by Euphausia superba during the Antarctic winter. Antarct J US 27:181-183

Pakhomov EA, Perissinotto R, Froneman PW, Miller DGM (1997) Energetics and feeding dynamics of Euphausia superba in the South Georgia region during summer of 1994. J Plankton Res 19:399-423

Parkinson CL (1992) Interannual variability of monthly Southern Ocean sea ice distributions. J Geophys Res 97: 5349-5363

Perissinotto R, Gurney L, Pakhomov EA (2000) Contributions of heterotrophic material to diet and energy budget of Antarctic krill, Euphausia superba. Mar Biol 136(1): $129-135$

> Price HJ, Boyd KR, Boyd CM (1988) Omnivorous feedingbehavior of the Antarctic krill Euphausia superba. Mar Biol 97:67-77

Quetin LB, Ross RM (1985) Feeding by Antarctic krill Euphausia superba: Does size matter? In: Siegfried WR, Condy PR, Laws RM (eds) Antarctic nutrient cycles and food webs. Springer Verlag, Berlin, p 372-377

Quetin LB, Ross RM (1991) Behavioral and physiological characteristics of the Antarctic krill, Euphausia superba. Am Zool 31:49-63

Quetin LB, Ross RM, Clarke A (1994) Krill energetics: seasonal and environmental aspects of the physiology of Euphausia superba. In: El-Sayed SZ (ed) Southern Ocean ecology: the BIOMASS perspective. Cambridge University Press, Cambridge, p 165-184

Roman MR (1983) Nitrogenous nutrition of marine invertebrates. In: Carpenter EJ, Capone DG (eds) Nitrogen in the marine environment. Academic Press, New York, p 347-383

Rönner U, Sörrenson F, Holm-Hansen O (1983) Nitrogen assimilation by phytoplankton in the Scotia Sea. Polar Biol 2:137-147

Roschke N, Schreiber W (1977) Analytik von Krill, Krillprodukten und antarktischen Fischen. Arch Fischereiwiss 28: 135-141

> Rosenberg AA, Beddington JR, Basson M (1986) Growth and longevity of krill during the first decade of pelagic whaling. Nature 324:152-154

Saether O, Ellingsen TE, Mohr V (1985) The distribution of 
lipid in the tissues of Antarctic krill, Euphausia superba. Comp Biochem Physiol 81B:609-661

Sargent JR, Henderson RJ (1986) Lipids. In: Corner EDS, O'Hara SCM (eds) The biological chemistry of marine copepods. Clarendon Press, Oxford, p 59-108

Sargent JR, Lee RF, Nevenzel JC (1976) Marine waxes. In: Kolattukudy P (ed) Chemistry and biochemistry of natural waxes. Elsevier Press, Amsterdam, p 50-91

Sargent JR, Gatten RR, Henderson RJ (1981) Lipid biochemistry of zooplankton from high latitudes. Oceanis 7: 623-632

Schnack SB (1985) Feeding by Euphausia superba and copepod species in response to varying concentrations of phytoplankton. In: Siegfried WR, Condy PR, Laws RM (eds) Antarctic nutrient cycles and food webs. Springer Verlag, Berlin, p 311-323

Scott CL, Kwasniewski S, Falk-Petersen S, Sargent JR (2002) Species differences, origins and functions of fatty alcohols and fatty acids in the wax esters and phospholipids of Calanus hyperboreus, C. glacialis and C. finmarchicus from Arctic waters. Mar Ecol Prog Ser 235:127-134

Siegel V, Nicol S (2000) Population parameters. In: Everson I (ed) Krill: biology, ecology and fisheries. Blackwell Science, Oxford, p 103-149

Smith WO, Nelson DM (1985) Phytoplankton bloom produced by a receding ice edge in the Ross Sea: spatial coherence with the density field. Science 227:163-166

Smith WO, Sakshaug E (1990) Polar phytoplankton, In: Smith WO (ed) Polar Oceanography, Part B, Chemistry, biology, and geology. Academic Press, San Diego, CA, p 477-525

Smith RC, Dierssen HM, Vernet M (1996) Phytoplankton biomass and productivity in the western Antarctic Peninsula region. In: Quetin LB, Hofmann EE, Ross RM (eds) Foundations for ecological research west of the Antarctic Peninsula. American Geophysical Union, Washington, DC, p 333-356

Smith WO, Mara J, Hiscock MR, Barber RT (2000) The sea-

Initial editorial responsibility: Howard Browman, Storebø,

Norway (until November 5, 2007); Final editorial responsibility:

Matthias Seaman, Oldendorf/Luhe, Germany sonal cycle of phytoplankton biomass and primary productivity in the Ross Sea, Antarctica. Deep-Sea Res II 47: 3119-3140

Stretch JJ, Hamner PP, Hamner WH, Michel WC, Cook J, Sullivan CW (1988) Foraging behavior of Antarctic krill Euphausia superba on sea ice microalgae. Mar Ecol Prog Ser 44:131-139

Strickland JDH (1960) Measuring the production of marine phytoplankton. Bull Fish Res Board Can 122:1-172

Teschke M, Kawaguchi S, Meyer B (2007) Simulated light regimes affect feeding and metabolism of Antarctic krill, Euphausia superba. Limnol Oceanogr 52(3):1046-1054

Torres JJ, Aarset AV, Donnelly J, Hopkins TL, Lancraft T, Ainley DG (1994) Metabolism of Antarctic micronektonic Crustacea as a function of depth occurrence and season. Mar Ecol Prog Ser 113:207-219

Tréguer P, Jacques G (1992) Dynamics of nutrients and phytoplankton, and fluxes of carbon, nitrogen and silicon in the Antarctic Ocean. Polar Biol 12:149-162

Villafañe VE, Helbling EW, Holm-Hansen O (1993) Phytoplankton around Elephant Island, Antarctica: distribution, biomass and composition. Polar Biol 13:183-191

Virtue P, Nichols PD, Nicol S (1997) Dietary-related mechanisms of survival in Euphausia superba: biochemical changes during long-term starvation and bacteria as a possible source of nutrition. In: Battaglia B, Valencia J, Dalton DWH (eds) Antarctic communities: species, structure and survival. Cambridge University Press, Cambridge, p 193-201

- Voronina NM, Kosobokova KN, Pakhomov EA (1994) Composition and biomass of summer metazoan plankton in the 0-200 m layer of the Atlantic sector of the Antarctic. Polar Biol 14:91-95

> Ward P, Atkinson A, Murray AWA, Wood AG, Williams R, Poulet SA (1995) The summer zooplankton community at South Georgia: biomass, vertical migration and grazing. Polar Biol 15:195-208

Submitted: May 3, 2007; Accepted: December 3, 2007

Proofs received from author(s): April 28, 2008 